\title{
Integrated Geophysical Study to Delineate Mineralised Zones in Southwest Ashanti Belt of Ghana
}

\author{
A. Ewusi, E. Adatsi, D. Aikins, J. Seidu \\ Geological Engineering Department, University of Mines and Technology, Tarkwa, Ghana \\ Email: aewusi@umat.edu.gh
}

How to cite this paper: Ewusi, A., Adatsi, E., Aikins, D. and Seidu, J. (2018) Integrated Geophysical Study to Delineate Mineralised Zones in Southwest Ashanti Belt of Ghana. Journal of Geoscience and Environment Protection, 6, 77-89. https://doi.org/10.4236/gep.2018.67006

Received: May 24, 2018

Accepted: July 17, 2018

Published: July 20, 2018

Copyright $\odot 2018$ by authors and Scientific Research Publishing Inc. This work is licensed under the Creative Commons Attribution International License (CC BY 4.0).

http://creativecommons.org/licenses/by/4.0/

\begin{abstract}
Ground Frequency Domain Electromagnetic (FDEM) and Magnetic surveys were conducted in Southwest of the Ashanti belt in the Western Region of Ghana. The aim was to delineate potential gold mineralisation zones that may occur within the area. The magnetic data processing steps involved analytic signal, first vertical derivative, upward continuation, CET grid analysis as well as depth to basement model (Werner deconvolution). For the electromagnetic survey using the two coil separations $(100 \mathrm{~m}$ and $150 \mathrm{~m})$ and the multi frequencies $(222 \mathrm{~Hz}, 888 \mathrm{~Hz}, 3555 \mathrm{~Hz})$, the data in-phase component was processed to produce EM component maps showing the potential mineralisation zones. Lineament analysis using the rose diagram showed that the area is dominated by N-S and NNW-SSE lineaments. The upward continuation and depth to the magnetic source bodies indicated that the magnetic bodies in the study area can be located at depth less than $200 \mathrm{~m}$.
\end{abstract}

\section{Keywords}

Frequency Domain, Electromagnetic Survey, Magnetic Survey, Southwest Ashanti Belt, Ghana

\section{Introduction}

Exploration methods such as soil sampling, stream sediment sampling, augur sampling, trenching and mapping etc. have been the major exploration methods for identifying mineralisation in gold exploration projects. This approach hasn't been entirely successful since answers to questions such as what fraction of a sample constitutes a representative sample at a location and whether the sample is in-situ or transported have not been adequately addressed. Also in thick 
overburden cover in deeply weathered terrains, some of the methods (soil sampling, trenching etc.) become ineffective. Furthermore, inadequate information in terms of structure, lithology and alteration is not obtained from these exploration methods especially in poorly exposed areas without outcrops. These shortfalls have resulted in unsuccessful drilling programmes due to delineation of wrong targets. In Marymia, Cortez Hills and Tomingley deposits in Australia, application of geophysics was used to highlight smaller shear zones within the structural corridor leading to the identification and effective delineation of the complex structures to depth [1]. At Banfara (Burkina Faso), after geochemical and structural geology had defined the main structural corridors, geophysical surveys were effective in delineating successful drill targets [2].

In these two studies enumerated, the integration of geophysics was regarded as a higher priority exploration method than either structural or geological mapping [1]. In this study, cost-effective geophysical studies (ground magnetic and electromagnetic) have been deployed in the Southwest of the Ashanti belt of Ghana to delineate potential gold mineralisation zones.

\section{The Study Area}

The study was conducted at Asuogya in the Tarkwa Nsuaem Municipality of the Western Region of Ghana. Asuogya is located south of the Tarkwa township which is approximately $200 \mathrm{~km}$ west of the capital Accra (Figure 1).

\section{Geology of the Study Area}

The study area is underlain by the Birimian rocks with a few undifferentiated detrital sediments of the Tarkwaian rocks (Figure 1). The Birimian rocks consist of volcanic, pyroclastic, and sedimentary rocks intruded by various types of granitoids. Volcanic belts are of tholeiitic basalt and andesite together with pyroclastic materials deposited in marine basins [3]. Chemical sediments precipitated contemporaneously on the flanks of volcanic rocks; they consist of manganese-rich rocks, chert, and rocks enriched in carbon, carbonates, or sulphides [3]. Porphyritic volcanic rocks and granitoids of calc-alkalic affinity may either be coeval with the tholeiitic rocks [3] [4] or postdate them. Parts of the volcanic belts are overlain by clastic strata of the Tarkwaian Group, which was probably deposited in graben structures formed by rifting [5].

Birimian and Tarkwaian rocks were affected by the Eburnean tectono-thermal event at 2100 to $2000 \mathrm{Ma}$ producing isoclinal folding and metamorphism that reached the greenschist to lower amphibolite facies. [6] suggested there were three deformations (D1, D2, D3) which affected the Birimian. The first deformation D1 (dated $2100 \mathrm{Ma}$ ) affected only the metasedimentary units of the Birimian whilst the D2 and D3 affected both the metasedimentary and metavolcanics rocks. The Eburnean event was accompanied by the intrusion of large masses of granitoids into the sedimentary-pyroclastic basins [7]. 


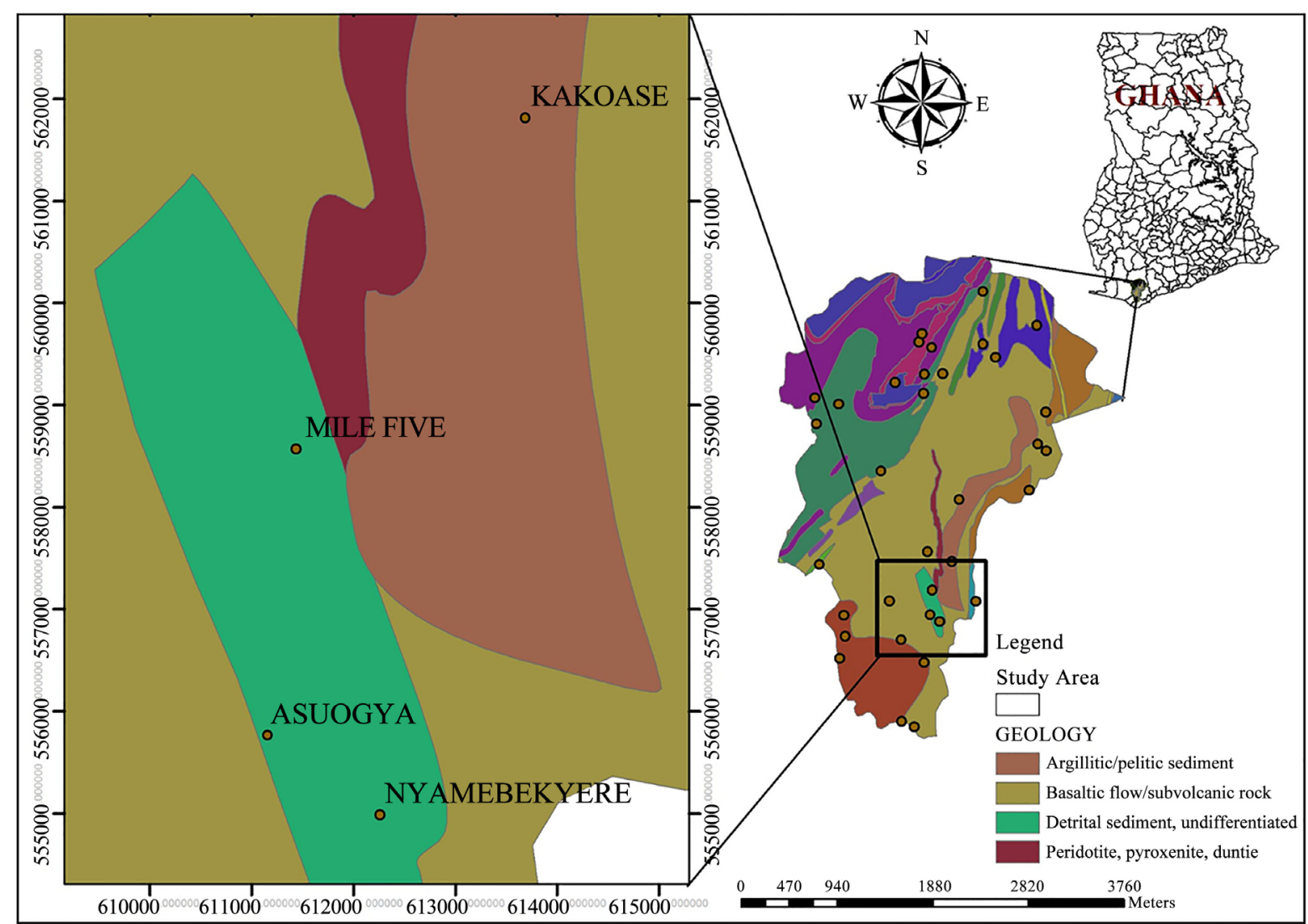

Figure 1. Geological map of the study area [8].

Two broad style of gold mineralisation are prevalent: paleo-placer disseminated gold deposits hosted within the Banket conglomerate of the Tarkwaian rocks and structurally controlled lode gold deposits hosted in a wide range of lithologies within the Birimian metavolcanic and metasedimentary rocks. Gold in the study area is associated with major NE striking $5 \mathrm{~m}$ to $40 \mathrm{~m}$ wide graphite-chlorite sericite fault zones. Deposits may develop where the NE fault zones intersect major NE striking fault zones. These faults are usually associated with pervasive hydrothermal alteration. The sulphides associated with the gold include pyrite, arsenophyrite, galena, pyrrhotite and sphalerite.

\section{Materials and Methods}

Field measurement was carried out to obtain data for the magnetic and electromagnetic surveys. The data for the magnetic survey was obtained by using two magnetometers a Scintrex Proton procession magnetometer for field measurements and Geometrics G856 Magnetometer for the base station readings. For the Electromagnetic survey the data was obtained using an Apex MaxMin II Electromagnetic equipment.

\subsection{Magnetic Field Data Collection}

The Scintrex Proton magnetometer measures the total magnetic intensity dis- 
tribution. In field operation, the sensor is mounted on a $2 \mathrm{~m}$ long aluminum pole to minimise the effect of cultural features on the surface. The sensor is kept at a constant height above the ground. Data sampling was done at $25 \mathrm{~m}$ on all the lines. The clocks in both magnetometers were synchronised and the base station magnetometer set in automatic mode for data recording every 3 seconds. At the base station the G856 proton precision magnetometer was placed to monitor the diurnal variations in the magnetic field in the area of the field measurements. The processing of Magnetic data involved validation and editing of the data, diurnal variation correction, geomagnetic correction and gridding of corrected data. All these were carried out with the Geosoft Oasis Montaj software.

The diurnally corrected and the IGRF corrected data was gridded with a cell size of 25 which is quarter of the line separation. The Residual Magnetic Intensity (RMI)) map of the study area where diurnal correction and IGRF have been removed is then obtained. The gridded Residual Magnetic data was presented on scaled maps to aid interpretation and georeferencing of anomalies and infrastructure data. In order to prepare the data for interpretation the RMI was further enhanced using filtering techniques such as: Directional Cosine Filter, Analytical Signal Amplitude (ASA), Upward Continuation (UC) and First Vertical Derivative (1 VD) which are computed in the wavenumber domain using Fast Fourier Transform (FFT) which are performed to improve the quality of the magnetic data to understand the subsurface geology [9] [10]. The CET grid analysis and the depth to basement model using Werner solutions were also conducted on the data.

\subsection{Electromagnetic Field Data Collection}

The electromagnetic survey was conducted using the frequency domain system. The Max Min II instrument measures the electromagnetic field which results from a conductive body; that is a structure which conducts electricity better than barren rock types. It consists of a transmitter and receiver units joined by a reference cable. It has five frequencies but only three, $222 \mathrm{~Hz}, 888 \mathrm{~Hz}$ and $3555 \mathrm{~Hz}$ were used in the horizontal loop mode to save time and efforts. Alternating current generated in the transmitter unit gives rise to primary magnetic signals which permeate the subsurface to induce secondary signals in buried conductors. The ratio of the secondary to the primary magnetic signals relates to the subsurface conductivity. The receiver was then used to measure the in-phase and out of phase components of the ratio. As mineralisation in the area is structurally controlled and often steeply dipping, the horizontal coplanar arrangement was adopted for the electromagnetic field measurements. In this arrangement, the axes of both the transmitter and receiver coils are oriented vertical to the plane containing both units. In this mode, the generated signals results in optimum induction of the electromagnetic fields in steeply dipping features for maximum detection by the receiver unit. During the survey, multiple measurements were made at the various stations on all the lines using the three different frequencies 
of $222 \mathrm{~Hz}, 888 \mathrm{~Hz}$ and $3555 \mathrm{~Hz}$. These were done for both transmitter receiver (Tx-Rx) coil separations of $100 \mathrm{~m}$ and $150 \mathrm{~m}$ with station interval of $25 \mathrm{~m}$ along the survey line. The different frequencies and the different $\mathrm{Tx}$-Rx separations used were chosen to obtain good resolution of near-surface conductors and search depth for deep conductors.

\section{Results and Discussion}

The results obtained after processing the EM and Magnetic field data of the study area include: gridded images and maps. These images include Residual Magnetic Intensity (RMI), Analytical Signal Amplitude (ASA), Upward Continuation (UC), First Vertical derivative (1VD) map and Structural Complexity Map using CET analysis, depth to basement models and anomaly maps for the Electromagnetic (EM) surveys. The RMI image was used in mapping the various lithological units while AS was used to place anomalies directly over their causative bodies because the source positions of the anomalies are defined vertically over the source irrespective of any remanence in magnetisation. The UC maps of the AS was used to interpret the signal from deep-seated or regional scale features while the 1VD and the structural complexity map were used to detect areas of structural complexity and locate deposit occurrence favourability. The anomaly maps produced from the EM surveys were used to describe the conductive zones in the study areas.

\subsection{Results of the Magnetic Survey}

The Residual Magnetic intensity map (Figure 2(a)) shows the spatial distribution of magnetic anomaly in the study area. From the analytic signal grid (Figure 2(b)), which placed the magnetic anomalies on their sources five anomalous regions were delineated labelled 1, 2, 3, 4 and 5. After applying the UC filter at $50 \mathrm{~m}$ (Figure 2(c)), $100 \mathrm{~m}$ (Figure 2(d)), $150 \mathrm{~m}$ (Figure 2(e)) and 200 $\mathrm{m}$ (Figure 2(f)) only four anomalies; 1, 2, 3, and 5 persisted at depth (Figure 2(f)) while the zone labelled 4 diminished showing that it might not persist at depth.

The structures identified from the IVD and structure complexity analysis (Figure 3(a)) suggested that the area that is likely to host precipitated ore fluids since the deposit type is hydrothermal. These zones 1,2, 3 and 5 which trend N-S (Figure 3(b)) were the potential mineralised zones identified from the processed magnetic data.

\subsection{Depth to Basement}

The Werner solution of the $\mathrm{P}$ depth extension form Oasis Montaj (which uses the horizontal and vertical derivatives of a magnetic signal in calculating the depth to basement of the magnetic anomaly), was used to investigate the depth of occurrence of the magnetic anomalies of the Asuogya area. The Werner Solution assumes the source bodies are either dikes or contacts with infinite depth extent and uses a least-squares approach to solve for the source body [11]. Six 


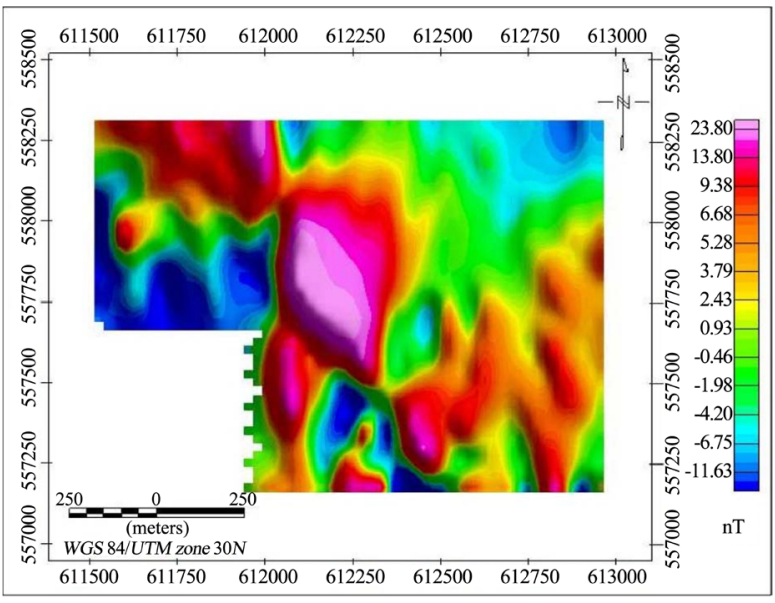

(a)

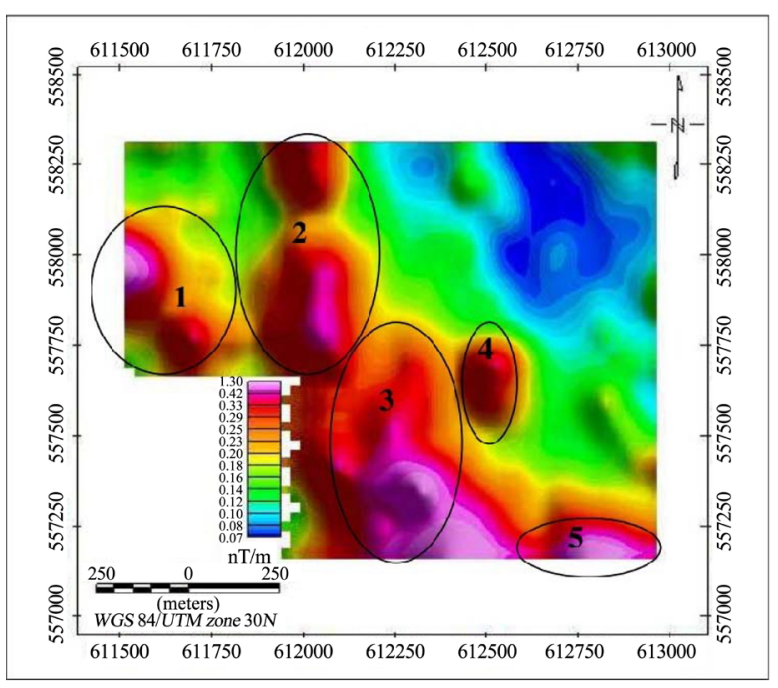

(c)

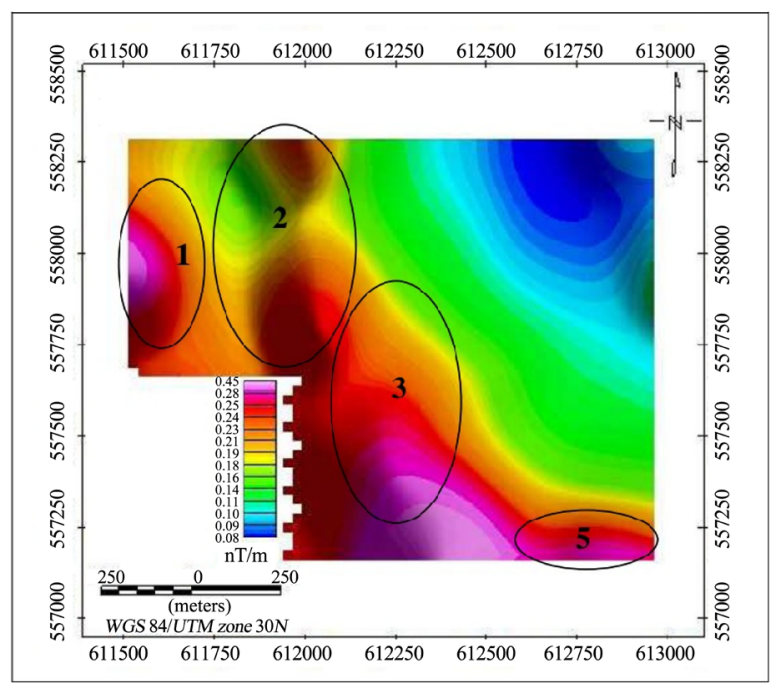

(e)

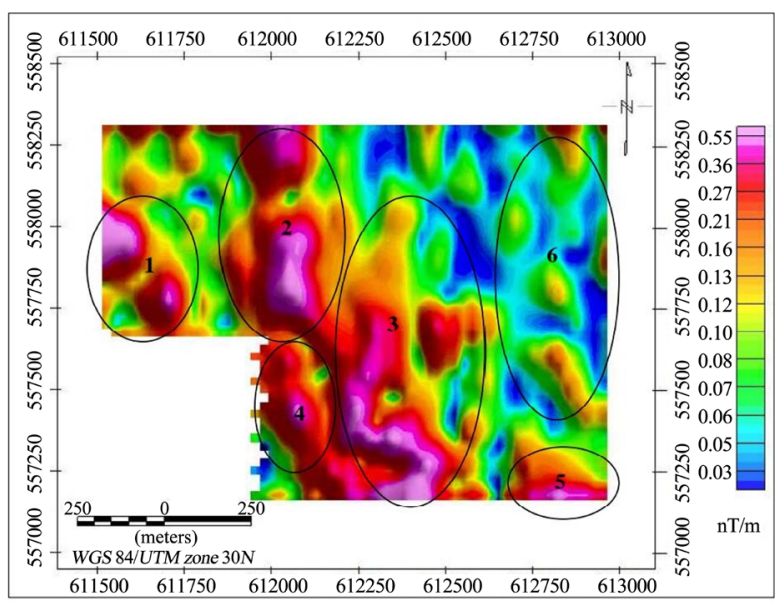

(b)

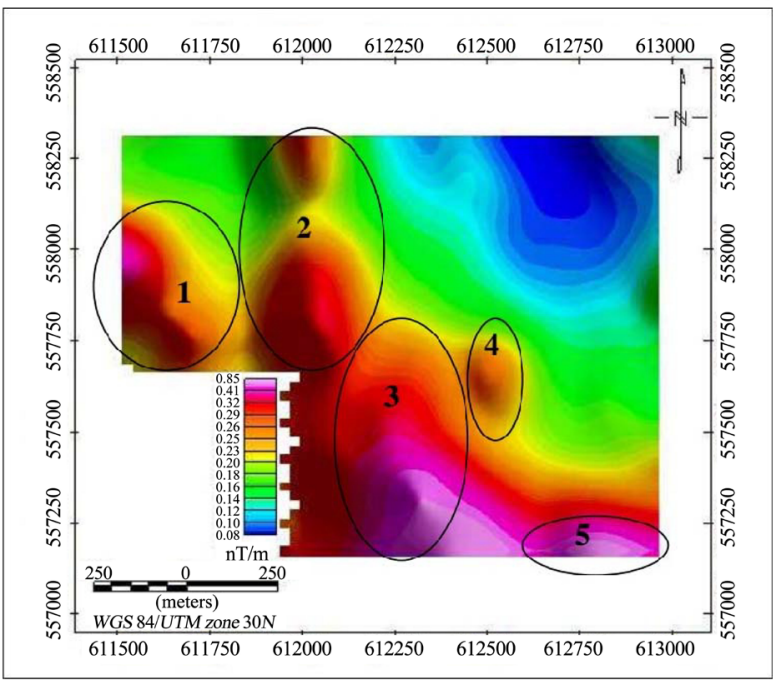

(d)

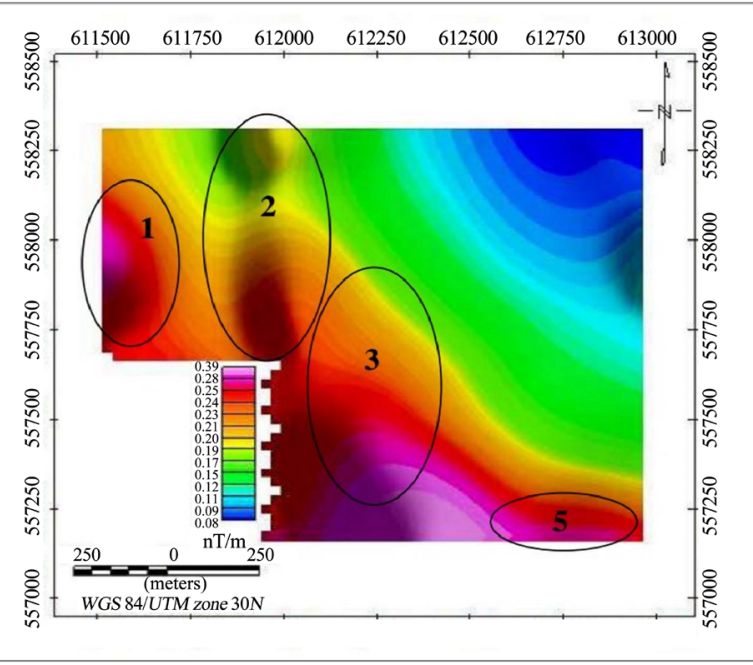

(f)

Figure 2. (a) Residual Magnetic Intensity Map; (b) Analytic Signal (AS) Map of Asuogya; (c) Upward Continued of the AS at $50 \mathrm{~m}$; (d) Upward Continued of AS at $100 \mathrm{~m}$; (e) Upward Continued of the AS at $150 \mathrm{~m}$; (f) Upward Continued of the AS at $200 \mathrm{~m}$. 


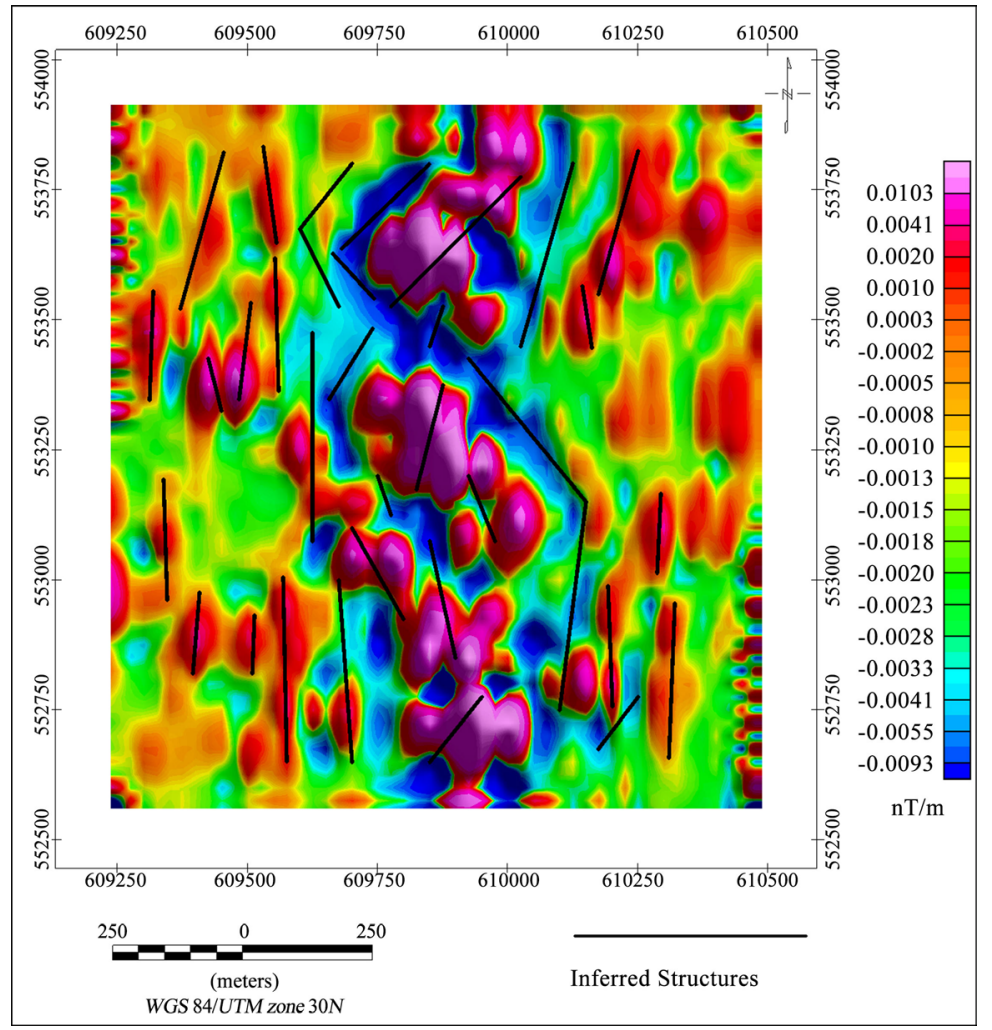

(a)

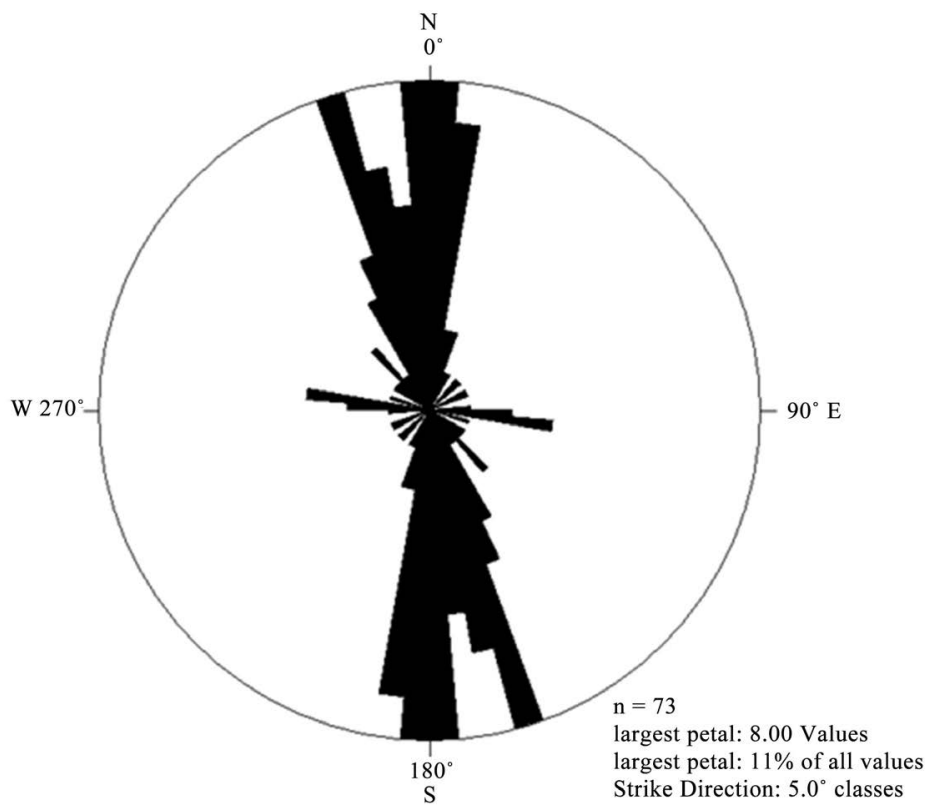

(b)

Figure 3. (a) First Vertical Derivative (1VD) and Structural Complexity Map of the Study Area; (b) Rose Diagram showing the N-S treading of the lineaments in the study.

profile lines namely S1, S2, S3, S4, S5 and S6 (Figure 4(a)), were mapped to transverse some zones of the magnetic anomalies from the associated rock formations. 


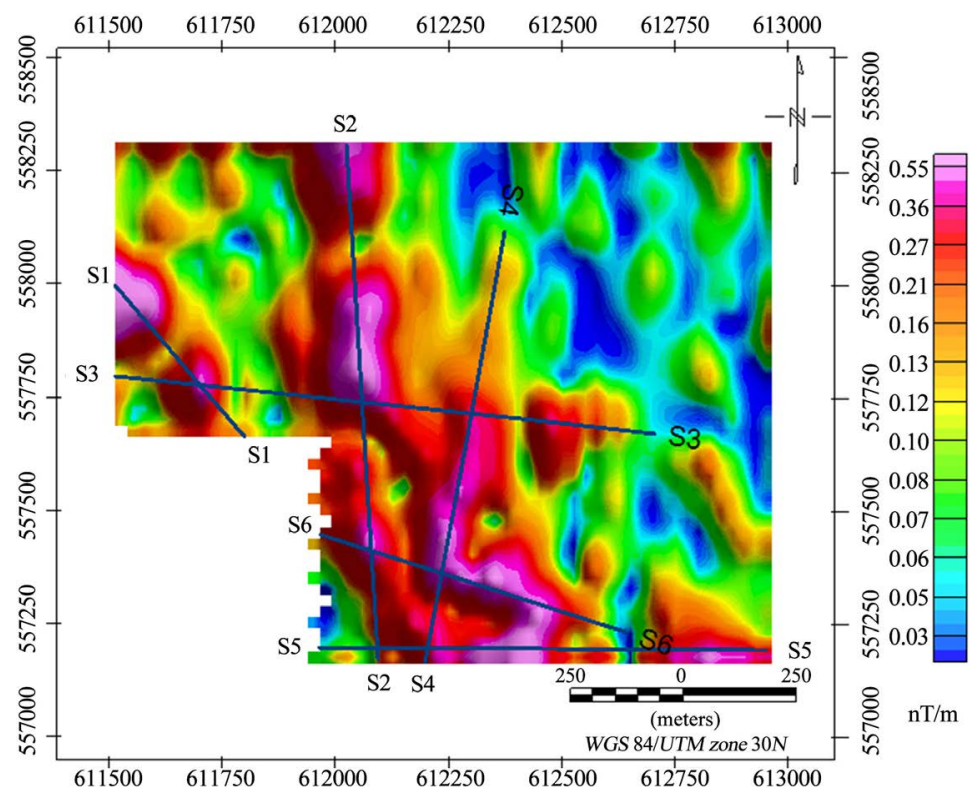

(a)

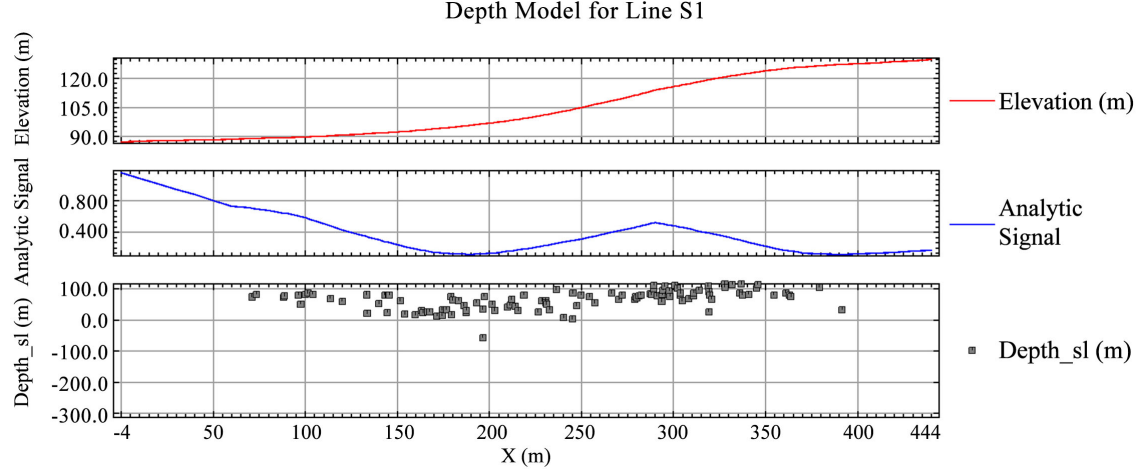

(b)

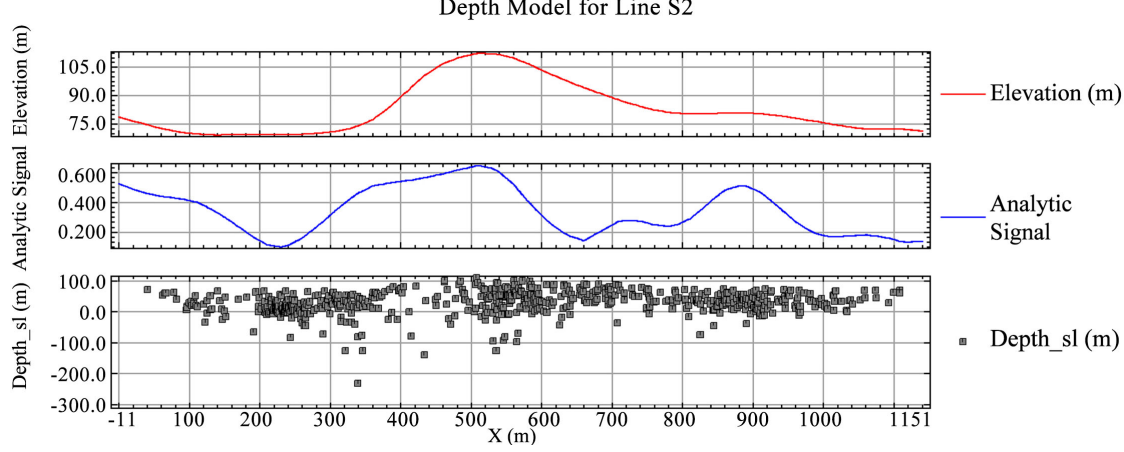

(c)

Figure 4. (a) Sections across Magnetic Anomalies of the Analytic Signal; (b) Depth to Basement Model for Line S1; (c) Depth to Basement Model for Line S2.

The elevation profile and analytic signal along section S1 (Figure 4(b)) ranges from $87 \mathrm{~m}$ to $129 \mathrm{~m}$ and $0.118 \mathrm{nT} / \mathrm{m}$ to $1.156 \mathrm{nT} / \mathrm{m}$ respectively. The depth of the magnetic anomalies ranges from $120.7 \mathrm{~m}$ above sea level to $57.9 \mathrm{~m}$ below sea 
level and averages at $64.9 \mathrm{~m}$ above sea level. Along section S2 (Figure 4(c)), the lowest elevation is $69.3 \mathrm{~m}$ while the highest is $112.3 \mathrm{~m}$. The depth to basement for section S2 ranges from $109.6 \mathrm{~m}$ to $232.7 \mathrm{~m}$. The profile shows that most of the magnetic bodies are at a depth of about $50 \mathrm{~m}$ above sea level with a few below sea level. An average elevation of $103.7 \mathrm{~m}$ was observed along section S3 (73.5 - 139.4) $\mathrm{m}$ above sea level). The analytic signal values range from 0.055 $\mathrm{nT} / \mathrm{m}$ to $0.521 \mathrm{nT} / \mathrm{m}$. The depths to the basement for the magnetic anomalies along section S3 is $127.2 \mathrm{~m}$ above sea level and $221 \mathrm{~m}$ below sea level. Along section S4, the elevation profile and analytical signal ranges from $(70.2-92.0) \mathrm{m}$ and $(0.110-0.620) \mathrm{nT} / \mathrm{m}$ respectively. The depth to the magnetic anomaly ranges from $100 \mathrm{~m}$ above sea level to $106 \mathrm{~m}$ below sea level. The analytical signal values observed for section S5 ranges from $(0.004-0.980) \mathrm{nT} / \mathrm{m}$ with elevation profile between $(72.0$ and 83.2$) \mathrm{m}$. The depth of the magnetic anomalies ranges from $70 \mathrm{~m}$ above sea level to $290 \mathrm{~m}$ below sea level. Along section S6, the elevation profile ranges between $72 \mathrm{~m}$ to $90 \mathrm{~m}$ with an analytical signal reading between $(0.160$ and 0.600$) \mathrm{nT} / \mathrm{m}$. The depth of the magnetic anomalies ranges from $88 \mathrm{~m}$ above sea level to $160 \mathrm{~m}$ below sea level.

The different range of values in the analytic signal values correlates with the magnetic causative bodies and their positions in the different rock units in the area. A substantial amount of the magnetic anomalies in the area have depths which are below sea level which shows the magnetic bodies along the sections are deep seated.

A summary of the analytical signal and depth along all the six sections is presented in Table 1. The depth models obtained for the sections S1, S2, S3, S4, S5 and S6 with each model displaying profiles of the elevation, analytic signal and depth showed that most of the anomalies persist at depth of $200 \mathrm{~m}$.

\subsection{Results of the EM Survey}

Results for EM survey also delineated potential mineralised zones of interest (Figure 5(a) to Figure 5(f)) at different coil separations of $100 \mathrm{~m}$ and $150 \mathrm{~m}$. All three (3) frequencies in conjunction with the different coil separations delineated anomalies which have been labelled as A, B, C and 1, 2 and 3 in the $100 \mathrm{~m}$

Table 1. Elevation, Analytical Signal and Depth to basement values along Sections.

\begin{tabular}{cccc}
\hline Section & $\begin{array}{c}\text { Elevation } \\
(\mathrm{m})\end{array}$ & Analytical Signal (nT/m) & $\begin{array}{c}\text { Depth to Basement } \\
(\mathrm{m})\end{array}$ \\
\hline S1 & $87-129$ & $0.118-1.156$ & $120.7^{\star}-57.9^{* *}$ \\
S2 & $69.3-112.3$ & $0.100-0.588$ & $109.6^{*}-232.7^{\star *}$ \\
S3 & $73.5-139.4$ & $0.055-0.521$ & $127.2^{\star}-221^{\star *}$ \\
S4 & $70.2-92.0$ & $0.110-0.620$ & $100^{*}-106^{\star *}$ \\
S5 & $72.0-83.2$ & $0.004-0.980$ & $70^{*}-290^{\star *}$ \\
S6 & $72.0-90.0$ & $0.160-0.600$ & $88^{\star}-160^{\star *}$ \\
\hline
\end{tabular}

*: above sea level, ${ }^{* *}$ : below sea level. 

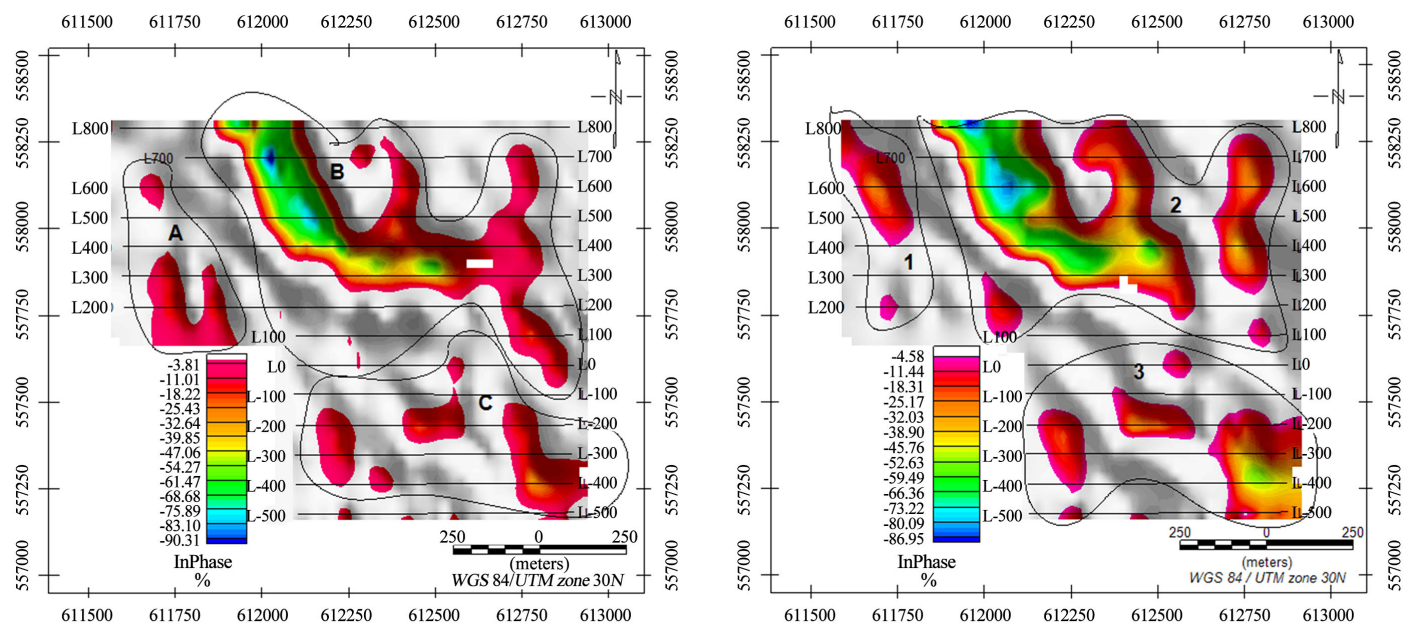

(a)

(b)
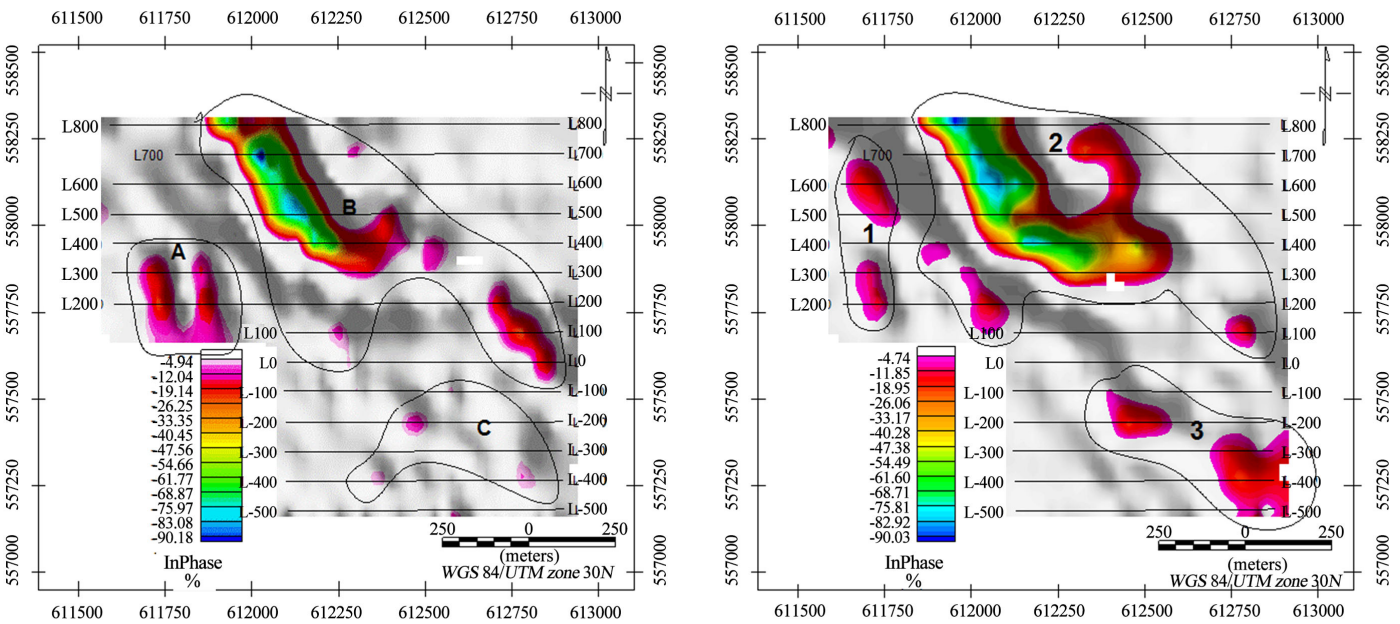

(c)

(d)

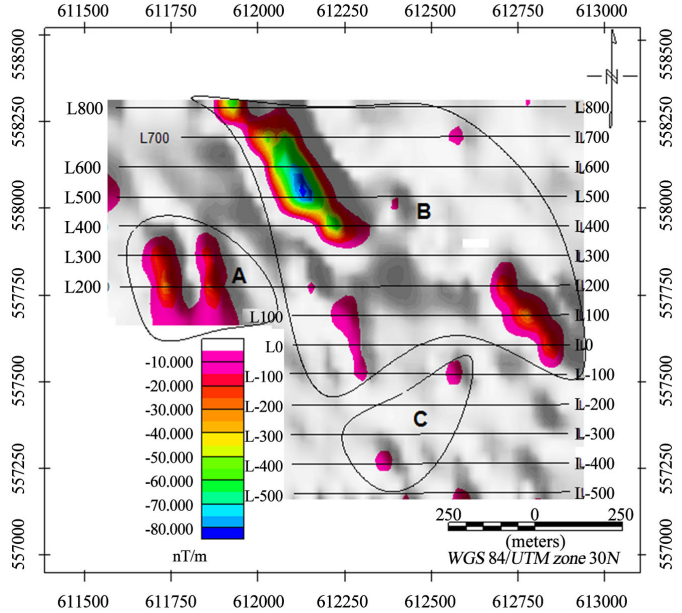

(e)

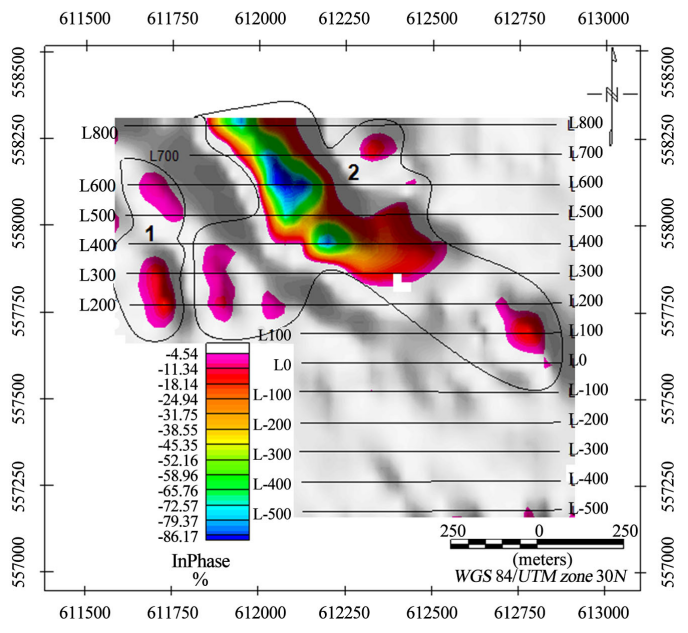

(f)

Figure 5. (a) In-Phase EM component map with coil separation of $100 \mathrm{~m}$ and Frequency $3555 \mathrm{~Hz}$; (b) In-Phase EM component map with coil separation of $150 \mathrm{~m}$ and Frequency $3555 \mathrm{~Hz}$; (c) In-Phase EM Component Map with coil separation of $100 \mathrm{~m}$ and Frequency $888 \mathrm{~Hz}$; (d) In-Phase EM Component Map with coil separation of $150 \mathrm{~m}$ and Frequency $888 \mathrm{~Hz}$; (e) In-Phase EM Component Map with coil separation of $100 \mathrm{~m}$ and Frequency $222 \mathrm{~Hz}$; (f) In-Phase EM Component Map with coil separation of $150 \mathrm{~m}$ and Frequency $222 \mathrm{~Hz}$. 
and $150 \mathrm{~m}$ coil separations respectively. In EM survey the lowest frequency probes deeper than higher frequencies and as such anomalies identified using low frequency are of prime importance. Therefore for the Asuogya area the zones label A, B and C (Figure 5(a)) for the $100 \mathrm{~m}$ coil separation at a frequency of $222 \mathrm{~Hz}$ are of prime importance while the zones labelled 1 and 2 (Figure 5(b)) for $150 \mathrm{~m}$ coil separation are the zones of interest. Anomaly A and B still persist (Figure 5(e)) just as 1 and 2. These zones can be identified as the potential zones of mineralisation in the area from the EM survey. These zones trend in the NNW-SSE and N-S directions.

Aside the fact that these anomalies persist at depth, they were also identified as potential mineralised zones because of their high conductivities and the structures (which may serve as the structural controls influencing gold mineralisation in the area) identified in these zones. These anomalous zones identified from both the EM and the magnetic surveys occurred in the Birimian metavolcanic, metasedimentary and Tarkwaian rocks (Figure 6) which are cross cut by linear structures possibly fractures, fissures, faults etc. which serve as conduits in which mineralised ore fluids may precipitate and crystallise. The mineralisation in this area consist of mesothermal gold mineralisation in sediments and volcanic hosted shear zones, associated with a major NE trending reverse fault along the Ashanti shear zone system and its Western splay.

\subsection{Potential Mineralisation Zones}

The anomalous zones delineated from both the magnetic and electromagnetic surveys were overlaid to determine areas where both anomalies intersect. The result is a potential mineralisation map shown in Figure 6. Three zones of intersection labelled MD were delineated. The zones delineated trend N-S and NW-SE.

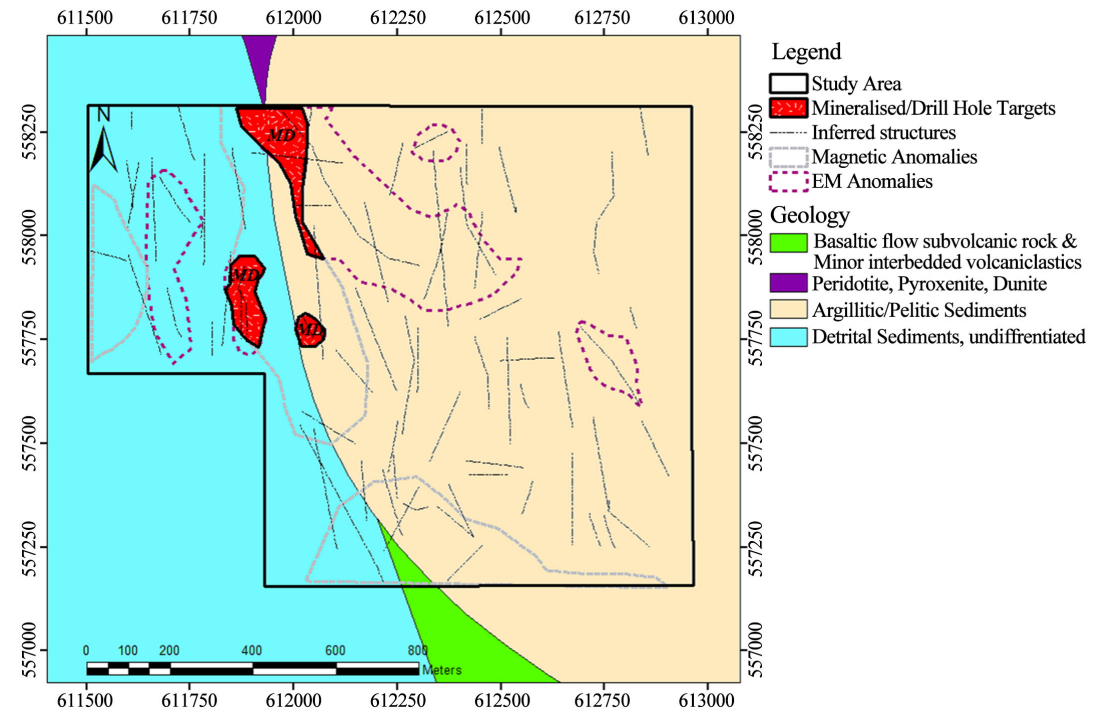

Figure 6. Potential mineralisation map and drill hole targets for asuogya 6. 


\section{Conclusion}

The Ground Electromagnetic and Magnetic Geophysical methods have been successfully used to delineate potential mineralisation zones at Asuogya. Three potential mineralisation zones have been delineated and are good targets for drilling. The zones delineated trend N-S and NE-SW. Mineralisations in Asuogya are linear features like quartz veins which contain sulphides. The results will improve upon the current understanding of mineralization of the Ashanti belt and the appropriate techniques that can be deployed to locate mineralised areas. This approach is suitable especially in areas of inadequate outcrops, thick overburden and illegal small scale mining activities that could result in false geochemical anomalies.

\section{References}

[1] Brown, L. and Vearncombe, J. (2014) "Critical Analysis of Successful Gold Exploration Methods", Applied Earth Science. Transactions of the Institution of Mining and Metallurgy. Section $B, 123,18-24$.

[2] Brooks, S.R. and Cameron, G.H. (2009) Banfora Discovery: A Granite Hosted Birimian Gold Deposit in South-Western Burkina Faso, New Generation Gold 2009. In: Yates, K., Ed., Proceedings of Conference of Case Histories of Discovery, Keith Yates and Associates Pty Ltd. and Paydirt Media Pty Ltd., 217-231.

[3] Leube, A., Hirdes, W., Mauer, R. and Kesse, G.O. (1990) The Early Proterozoic Birimian Supergroup of Ghana and Some Aspects of Its Associated Gold Mineralization. Precambrian Research, 46, 139-165. https://doi.org/10.1016/0301-9268(90)90070-7

[4] Sylvester, P.J. and Attoh, K. (1992) Lithostratigraphy and Composition of $2.1 \mathrm{Ga}$ Greenstone Belts of the West African Craton and Their Bearing on Crustal Evolution and the Arehean-Proterozoic Boundary. The Journal of Geology, 100, 377-393. https://doi.org/10.1086/629593

[5] Goodwin, A.M. (1991) Precambrian Geology. The Dynamic Evolution of the Continental Crust. Academic Press, London, 666 p.

[6] Milesi, J.P., Feybesse, J.L. and Ledru, P. (1989) Les mineralisations auriferes de l'Afrique de l'Ouest. Leur evolution lithostructurale au Proterozoique inferieur, Carte metallogenique a 1/2 000 000. Chronique de la Recherché Miniere, France, 497, 98.

[7] Hirdes, W., Davis, D.W. and Eisenlohr, B.N. (1992) Reassessment of Proterozoic Granitoid Ages in Ghana on the Basis of U/Pb Zircon and Monazite Dating. Precambrian Research, 56, 89-96. https://doi.org/10.1016/0301-9268(92)90085-3

[8] Ghana Geological Survey. (2009) Geological Map of Ghana-1:1000000. Geological Survey Department, Accra, Ghana.

[9] Hildenbrand, R., Hinze, W., Keller, G.R., Labson, L. and Roest, W. (2003) New and Unique U.S. Magnetic Database Is Forthcoming. The Leading Edge, 22, 234-244. https://doi.org/10.1190/1.1885534

[10] Hinze, J., Aiken, C., Brozena, J., Coakley, B., Dater, D., Flanagan, G., Forsberg, R., Hildenbrand, T., Keller, G.R., Kellogg, J., Kucks, R., Li, X., Mainville, A., Morin, R., Pilkington, M., Plouff, D., Ravat, D., Roman, D., Urrutia-Fucugauchi, J., V'eronneau, M., Webring, M. and Winester, D. (2005) New Standards for Reducing 
Gravity Data. The North American Gravity Database. Geophysics, 70, 25-32. https://doi.org/10.1190/1.1988183

[11] Ku, C. and Sharp, J. (1983) Werner Deconvolution for Automated Magnetic Interpretation and Its Refinement Using Marquart's Inverse Modelling. Geophysics, 48, 754-774. https://doi.org/10.1190/1.1441505 